\title{
Edible crickets, but which species?
}

\author{
A. van Huis \\ Laboratory of Entomology, Wageningen University E Research, P.O. Box 16, 6700 AA Wageningen, the Netherlands; \\ editor-in-chief@insectsasfoodandfeed.com
}

\section{OPEN ACCESS (C) (i) () (2)}

EDITORIAL

(c) 2020 Wageningen Academic Publishers

\begin{abstract}
True crickets belong to the family of the Gryllidae and they can be used not only as food and feed, but also for recreational purposes (fighting or singing). When reared on cheap substrates, they can be used as feed. The house cricket is most often used as human food. The selection of the cricket species may depend on several criteria, such as legislation, resistance to disease, but also taste.
\end{abstract}

\section{Introduction}

The suborder Ensifera (Orthoptera) includes true crickets, camel crickets, bush crickets or katydids, and others. The true crickets belong to the family Gryllidae (Orthoptera). The bush crickets or katydids belong to the family Tettigonidae containing a number of edible insect species such as the Mormon cricket (Anabrus simplex) used as feed for poultry in the USA (DeFoliart et al., 1982; Finke et al., 1985), the armoured cricket (Acanthoplus discoidalis) consumed as relish and snack in Zimbabwe (Mugova et al., 2018), and the bush cricket Ruspolia differens, considered to be delicious human food in East Africa (Malinga et al., 2018). Of the closely related family of the Stenopelmatidae, the edible ground cricket Henicus whellani is eaten in southeastern Zimbabwe (Musundire et al., 2014). However, we will restrict ourselves here to the family Gryllidae which includes more than 550 species in the world (Rentz and $\mathrm{Su}, 2003)$. This article is also meant to motivate authors to be more precise about which cricket species they are referring to, because there are several occasions where it is not mentioned (Lokman et al., 2019); this may be because the authors consider the house cricket the default or did not think it relevant.

\section{Uses of crickets}

The house cricket, Acheta domesticus, is a domesticated species used as food for mammals, birds and reptiles. These domesticated strains may have difficulties surviving in nature. In Asian countries, crickets are kept for fighting and for their song. The fighting crickets are probably Teleogryllus mitratus (Kevan and Hsiung, 1976) in China and Velarifictorus beybienkoi and Velarifictorus micado in Japan (Suga, 2006). In China, India, Indonesia, Japan and Korea, Homeogryllus japonicus is used for singing, and is called 'golden bell' in Japanese, because of its beautiful sound (Pemberton, 2002; Ryan, 1996). Nocturnal crickets are best known for the loud, persistent, chirping song of the males.

\subsection{Crickets as feed}

Most reared cricket species are used as human food (very often A. domesticus) or for insectivorous amphibians and reptiles. However, a few publications mention insects as feed for common production animals and pets:

- Fish: A. domesticus (Irungu et al., 2018; Lee et al., 2017), Gryllus assimilis (Alfaro et al., 2019), and Gryllus bimaculatus (Norhidayah, 2016; Taufek et al., 2018).

- Feed: G. bimaculatus (Straub et al., 2019); in Indonesia: Gryllus mitratus $^{1}$, G. bimaculatus and Gryllus testaceus ${ }^{1}$ (Armansyah and Handayani, 2020; Fuah et al., 2015).

- Pigs: G. testaceus ${ }^{1}$ (Miech et al., 2017).

- Poultry (Lokman et al., 2019): A. domesticus (Kovitvadhi et al., 2019; Nakagaki et al., 1987), G. testaceus $^{1}$ (Kovitvadhi et al., 2019; Miech et al., 2016) and G. bimaculatus (Kovitvadhi et al., 2019).

- Japanese quail (Coturnix japonica) eggs: G. bimaculatus (Permatahatia et al., 2019).

- Pets such as dogs: Gryllodes sigillatus (Jarett et al., 2019).

\footnotetext{
${ }^{1}$ According to Jongema (2017) Teleogryllus mitratus is synonymous with Teleogryllus testaceus, Gryllus mitratus and Gryllus testaceus.
} 
One could question the profitability of growing crickets for production animals, when they can be eaten directly by humans. The main reason is that it may be quite cheap when rearing crickets on weeds or organic side streams such as cassava leaves (Armansyah and Handayani, 2020; Caparros Megido et al., 2016; Choo et al., 2017; Fuah et al., 2015; Miech et al., 2016; Thu Hang et al., 2020).

\subsection{Crickets as food}

Edible crickets in particular have been domesticated in Thailand where 20,000 farmers produce 7,500 tons per year (Hanboonsong et al., 2013). In 1998, they started to rear three native species: G. bimaculatus, T. mitratus ${ }^{1}$ and Teleogryllus occipitalis. However, a few years later, $A$. domesticus was introduced from Europe and the USA (also in Laos; Hanboonsong and Durst, 2014). A. domesticus is now commonly farmed in Thailand. The reason for the shift is probably the taste, particularly of the females owing to the large number of eggs, which are 'delightful crunchy'. Other cricket species eaten in Thailand are the bull cricket Brachytrupes portentosus, the largest members of the Gryllidae family, and species like Gymnogryllus spp., Velarifictorus sp. and Modicogryllus confirmatus. In Java Indonesia the cricket T. mitratus ${ }^{1}$ is also farmed as food (Fuah et al., 2015). In Madagascar the large cricket Brachytrupes membranaceus colosseus is sold individually (3-6 dollar cents) and specifically sought after when meat is expensive and when no other rice accompaniments are available (Van Itterbeeck et al., 2019). The same publication mentions several other edible cricket species such as Modicogryllus sp. and Fryerius sp. In Kenya $B$. membranaceus is popular and traditionally consumed, but difficult to rear. In this country a new native edible cricket species, Scapsipedus icipe, has been described for the first time and has been suggested for mass rearing (Magara et al., 2019).

In different countries of Asia and Africa, A. domesticus and G. bimaculatus are reared by farmers (Halloran et al., 2018). The advantages of the first include nutritional value, soft tissue, low maintenance, low disease incidence, and the ability to consume a wide variety of foods including organic waste flows. Others prefer G. bimaculatus because they require less time to mature than the house cricket, 42 and 49 days, respectively (Halloran et al., 2017), and they are larger and easier to sell.

\subsection{Taste}

Is taste a selection criterion for a certain cricket species? Ribeiro et al. (2019) compared A. domesticus with G. sigillatus and found that when defatted there was no difference in flavour. However, when using whole crickets, there was a difference, probably due to the lipid content, which gives crickets a characteristic flavour.

\subsection{Diseases}

Cricket species may differ in their susceptibility to disease. An overview of which cricket species is susceptible to which disease is given by Eilenberg et al. (2017). A publication from the USA (Weissman et al., 2012) mentioned that the Acheta domesticus densovirus caused the collapse of commercial colonies of the house cricket. It was recommended to substitute it with G. sigillatus. Gryllus assimilis and G. bimaculatus also seem to be resistant to the virus (Szelei et al., 2011). Also, a nudivirus of G. bimaculatus is lethal to other cricket species such as G. campestris, Teleogryllus oceanicus and Teleogryllus commodus (Huger, 1985). However, disease prevention is also a matter of maintaining the colony in optimal condition and enforcing strict hygiene measures.

\subsection{Other criteria for selecting cricket species}

In specific countries there may be legislation concerning the legality of breeding certain cricket species (Mariod, 2020). The websites of commercial insect rearing companies also list the pros and cons of several cricket species, using criteria such as such being active, digestible, producing minimal noise, or odour, and not being aggressive.

\section{Conclusions}

For centuries crickets have been used to entertain people in China and Japan. They were kept as pets either for their characteristic sound or to be used in fighting matches. Nowadays, crickets are reared commercially as feed for amphibians and reptiles, and recently also as feed for fish, poultry and pigs. Since the last twenty years, starting in Thailand, they have also been used commercially as human food, the most popular being A. domesticus and G. bimaculatus. Large companies have emerged, rearing crickets for human consumption. The criteria for selecting the species include legislation, ease of rearing, selling price, taste, disease and size.

\section{References}

Alfaro, A.O., Núñez, W., Marcia, J. and Montero Fernández, I., 2019. The cricket (Gryllus assimilis) as an alternative food versus commercial concentrate for tilapia (Oreochromis sp.) in the nursery stage. Journal of Agricultural Science 11: 97-104, https://doi. org/10.5539/jas.v11n6p97.

Armansyah, V. and Handayani, M.T., 2020. Utilization potential in Cibanteng village for integration of agriculture-animal husbandry 'cricket cultivation'. Jurnal Pusat Inovasi Masyarakat 2: 108-116. 
Caparros Megido, R., Alabi, T., Nieus, C., Blecker, C., Danthine, S., Bogaert, J., Haubruge, É. and Francis, F., 2016. Optimisation of a cheap and residential small-scale production of edible crickets with local by-products as an alternative protein-rich human food source in Ratanakiri Province, Cambodia. Journal of the Science of Food and Agriculture 96: 627-632, https://doi.org/10.1002/jsfa.7133.

Choo, Y.R., Yan, A.T., Loh, R.H.J., Chin, Z.Y., Jo, C.S., Lee, K.E.M., Tan, M.K. and Tan, H.T.W., 2017. Can waste vegetables and weeds be used to farm crickets and grasshoppers in Singapore? A laboratory experiment on the use of vegetables and weeds for farming crickets and grasshoppers. Utar Agriculture Science Journal 3: 18-22.

DeFoliart, G.R., Finke, M.D. and Sunde, M.L., 1982. Potential value of the mormon cricket (Orthoptera: Tettigoniidae) harvested as a high-protein feed for poultry. Journal of Economic Entomology 75: 852-858, https://doi.org/10.1093/jee/75.5.848.

Eilenberg, J., Gasque, S.N. and Ros, V.I.D., 2017. Natural enemies in insect production systems. In: Van Huis, A. and Tomberlin, J.K. (eds.) Insects as food and feed: from production to consumption. Wageningen Academic Publishers, Wageningen, the Netherlands, pp. 201-223.

Finke, M.D., Sunde, M.L. and Defoliart, G.R., 1985. An evaluation of the protein quality of mormon crickets (Anabrus simplex Haldeman) when used as a high protein feedstuff for poultry. Poultry Science 64: 708-712, https://doi.org/10.3382/ps.0640708.

Fuah, A.M., Siregar, H.C.H. and Endrawati, C., 2015. Cricket farming for animal protein as profitable business for small farmers in Indonesia. Journal of Agricultural Science and Technology A 5: 296-304, https://doi.org/10.17265/2161-6256/2015.04.008.

Halloran, A., Hanboonsong, Y., Roos, N. and Bruun, S., 2017. Life cycle assessment of cricket farming in north-eastern Thailand. Journal of Cleaner Production 156: 83-94, https://doi.org/10.1016/j. jclepro.2017.04.017.

Halloran, A., Megido, R.C., Oloo, J., Weigel, T., Nsevolo, P. and Francis, F., 2018. Comparative aspects of cricket farming in Thailand, Cambodia, Lao People's Democratic Republic, Democratic Republic of the Congo and Kenya. Journal of Insects as Food and Feed 4: 101-114, https://doi.org/10.3920/JIFF2017.0016.

Hanboonsong, Y. and Durst, P.B., 2014. Edible insects in Lao PDR: building on tradition to enhance food security. Food and Agriculture Organization of the United Nations. Regional Office for Asia and The Pacific, Bangkok, https://www.fao.org/3/a-i3749e.pdf.

Hanboonsong, Y., T. Jamjanya, T. and P.B. Durst, P., 2013. Six-legged livestock: edible insect farming, collection and marketing in Thailand. Food and Agriculture Organization of the United Nations, Regional Office for Asia and the Pacific, Bangkok, https://www. fao.org/3/a-i3246e.pdf.

Huger, A.M., 1985. A new virus disease of crickets (Orthoptera: Gryllidae) causing macronucleosis of fatbody. Journal of Invertebrate Pathology 45: 108-111. https://doi.org/10.1016/0022-2011(85)900552.

Irungu, F.G., Mutungi, C.M., Faraj, A.K., Affognon, H., Kibet, N., Tanga, C., Ekesi, S., Nakimbugwe, D. and Fiaboe, K.K.M., 2018. Physico-chemical properties of extruded aquafeed pellets containing black soldier fly (Hermetia illucens) larvae and adult cricket (Acheta domesticus) meals. Journal of Insects as Food and Feed 4: 19-30, https://doi.org/10.3920/JIFF2017.0008.
Jarett, J.K., Carlson, A., Rossoni Serao, M., Strickland, J., Serfilippi, L. and Ganz, H.H., 2019. Diets with and without edible cricket support a similar level of diversity in the gut microbiome of dogs. PeerJ: 7, https://doi.org/10.7717/peerj.7661.

Jongema, Y., 2017. List of edible insect species of the world. Wageningen University \& Research, Wageningen, the Netherlands. Available at: https://tinyurl.com/mestm6p.

Kevan, D.K.M. and Hsiung, C.C., 1976. Cricket-fighting in Hong Kong. Bulletin of the Entomological Society of Canada 8: 11-12.

Kovitvadhi, A., Chundang, P., Luapan, J., Amarapitak, P., Sriyaphai, P., Buahom, R., Cham-iam, T., Leelehapongsathon, K., Tirawattanawanich, C. and Thongprajukaew, K., 2019. Cricket powder as an alternative protein source for broilers based on in vitro digestibility. Journal of Insects as Food and Feed 5: 185-191, https://doi.org/10.3920/JIFF2018.0043.

Lee, S.W., Tey, H.C., Wendy, W. and Zahari, M.W., 2017. The effect of house cricket (Acheta domesticus) meal on growth performance of red hybrid tilapia (Oreochromis sp.). International Journal of Aquatic Science 8: 78-82. https://www.journal-aquaticscience.com/article_ 70730_8a54b492509a1a1602b71000bc68f8ff.pdf.

Lokman, I.H., Ibitoye, E.B., Hezmee, M.N.M., Goh, Y.M., Zuki, A.B.Z. and Jimoh, A.A., 2019. Effects of chitin and chitosan from cricket and shrimp on growth and carcass performance of broiler chickens. Tropical Animal Health and Production 51: 2219-2225, https://doi. org/10.1007/s11250-019-01936-9.

Malinga, G. M., Valtonen, A., Lehtovaara, V.J., Rutaro, Opoke, R., Nyeko, P. and Roininen, H., 2018. Diet acceptance and preference of the edible grasshopper Ruspolia differens (Orthoptera: Tettigoniidae). Applied Entomology and Zoology 53: 229-236, https://doi.org/10.1007/s13355-018-0550-3.

Magara, H.J.O., Tanga, C.M., Ayieko, M.A., Hugel, S., Mohamed, S.A., Khamis, F.M., Salifu, D., Niassy, S., Sevgan, S., Fiaboe, K.K.M., Roos, N. and Ekesi, S., 2019. Performance of newly described native edible cricket Scapsipedus icipe (Orthoptera: Gryllidae) on various diets of relevance for farming. Journal of Economic Entomology 112: 653-664, https://doi.org/10.1093/jee/toy397.

Mariod, A.A., 2020. The legislative status of edible insects in the world. In: Adam Mariod, A. (ed.) African edible insects as alternative source of food, oil, protein and bioactive components. Springer International Publishing, Cham, pp. 141-148, https://doi. org/10.1007/978-3-030-32952-5_9.

Miech, P., Berggren, Å., Lindberg, J.E., Chhay, T., Khieu, B. and Jansson, A., 2016. Growth and survival of reared Cambodian field crickets (Teleogryllus testaceus) fed weeds, agricultural and food industry by-products. Journal of Insects as Food and Feed 2: 285-292, https:// doi.org/10.3920/JIFF2016.0028.

Miech, P., Lindberg, J.E., Berggren, Å., Chhay, T. and Jansson, A., 2017. Apparent faecal digestibility and nitrogen retention in piglets fed whole and peeled Cambodian field cricket meal. Journal of Insects as Food and Feed 3: 279-288, https://doi.org/10.3920/jiff2017.0019.

Mugova, A.K., Zvidzai, C.J. and Musundire, R., 2018. A survey on entomophagy practice of the armoured cricket (Acanthoplus discoidalis) in Mashonaland Central, Zimbabwe. International Journal of Pure and Applied Bioscience 6: 718-724, https://dx.doi. org/10.18782/2320-7051.6782. 
Musundire, R., Zvidzai, C.J., Chidewe, C., Samende, B.K. and Manditsera, F.A., 2014. Nutrient and anti-nutrient composition of Henicus whellani (Orthoptera: Stenopelmatidae), an edible ground cricket, in south-eastern Zimbabwe. International Journal of Tropical Insect Science 34: 223-231, https://doi.org/10.1017/ S1742758414000484.

Nakagaki, B.J., Sunde, M.L. and Defoliart, G.R., 1987. Protein quality of the house cricket, Acheta domesticus, when fed to broiler chicks. Poultry Science 66: 1367-1371, https://doi.org/10.3382/ps.0661367.

Norhidayah, M.T., 2016. Cricket meal as an alternative to fishmeal in diets for African catfish (Clarias gariepinus). PhD thesis, University of Malaya, Kuala Lumpur.

Pemberton, R.C., 2002. Persistence and change in traditional uses of insects in comtemporary East Asian cultures. In: Motte-Florac, E. and Thomas, J.M.C. (eds.) Les insectes dans la tradition oral. Peeters-SELAF, Paris, France, pp. 141-154.

Permatahatia, D., Mutiab, R. and Astuti, D.A., 2019. Effect of cricket meal (Gryllus bimaculatus) on production and physical quality of Japanese quail egg. Tropical Animal Science Journal 42: 53-58, https://doi.org/10.5398/tasj.2019.42.1.53.

Rentz, D.C.F. and Su, Y.N., 2003. Orthoptera (grasshoppers, locusts, katydids, crickets). In: Resh, V.H. and Cardé, R.T. (eds.) Encyclopedia of insects. Academic Press, Amsterdam, the Netherlands, pp. 827839.

Ribeiro, J.C., Lima, R.C., Maia, M.R.G., Almeida, A.A., Fonseca, A.J.M., Cabrita, A.R.J. and Cunha, L.M., 2019. Impact of defatting freezedried edible crickets (Acheta domesticus and Gryllodes sigillatus) on the nutritive value, overall liking and sensory profile of cereal bars. LWT 113: 108335, https://doi.org/10.1016/j.lwt.2019.108335.

Ryan, L.G., 1996. Insect musicians \& cricket champions: a cultural history of singing insects in China and Japan. China Books and Periodicals, Inc., San Francisco, CA, USA.
Straub, P., Tanga, C.M., Osuga, I., Windisch, W. and Subramanian, S., 2019. Experimental feeding studies with crickets and locusts on the use of feed mixtures composed of storable feed materials commonly used in livestock production. Animal Feed Science and Technology: 255, 114215, https://doi.org/10.1016/j.anifeedsci.2019.114215.

Suga, Y., 2006. Chinese cricket-fighting. International Journal of Asian Studies 3: 77-93, https://doi.org/10.1017|S1479591405000239.

Szelei, J., Woodring, J., Goettel, M.S., Duke, G., Jousset, F.X., Liu, K.Y., Zadori, Z., Li, Y., Styer, E., Boucias, D.G., Kleespies, R.G., Bergoin, M. and Tijssen, P., 2011. Susceptibility of North-American and European crickets to Acheta domesticus densovirus (AdDNV) and associated epizootics. Journal of Invertebrate Pathology 106: 394-399, https://doi.org/10.1016/j.jip.2010.12.009.

Taufek, N.M., Simarani, K., Muin, H., Aspani, F., Raji, A.A., Alias, Z. and Razak, S.A., 2018. Inclusion of cricket (Gryllus bimaculatus) meal in African catfish (Clarias gariepinus) feed influences disease resistance. Journal of Fisheries, https://dx.doi.org/10.17017/jfish. v6i2.2018.264.

Thu Hang, B.P., Van Cop, N. and V, L., 2020. Effect of cassava leaves (Manihot esculenta Crantz), water spinach (Ipomoea aquatica) and Coccinia grandis L. on biomass growth of crickets (Gryllus bimaculatus) fed chicken feed as the basal diet. Livestock Research for Rural Development 32, article 28, https://www.lrrd.org/lrrd32/2/ bpthan32028.html.

Van Itterbeeck, J., Rakotomalala, I.N.A., Faneva I Rajemison, Johanna F. Rakotondrasoa, Valisoa R. Ralantoarinaivo, Hugel, S. and Fisher, B.L., 2019. Diversity and use of edible grasshoppers, locusts, crickets, and katydids (Orthoptera) in Madagascar. Foods 8: 666, https://doi. org/10.3390/foods8120666.

Weissman, D.B., Gray, D.A., Pham, H.T. and Tijssen, P., 2012. Billions and billions sold: pet-feeder crickets (Orthoptera: Gryllidae), commercial cricket farms, an epizootic densovirus, and government regulations make for a potential disaster. Zootaxa 3504: 67-88, https://doi.org/10.11646/zootaxa.3504.1.3. 